\title{
Role of Convalescent Plasma Therapy in Successful Prevention and Treatment of Covid-19 Novel Corona Virus Critical Patients, In 2020 Global Pandemic
}

\author{
Ahsan Siddiqui, M.D, M.S.P.H (UK)* \\ Department of Quality Management \& Patient Safety, General Directorate of Health, Saudi Arabia \\ *Corresponding author: Ahsan Ali Siddiqui, Consultant Epidemiologist, Quality Management \& Patient Safety, Departmeı \\ General Directorate of Health, Riyadh Saudi Arabia
}

\section{ARTICLE INFO}

Received: 幽 March 14, 2020

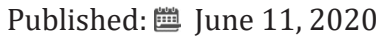

Citation: Ahsan Ali Siddiqui. Role of Convalescent Plasma Therapy in Successful Prevention and Treatment of Covid-19 Novel Corona Virus Critical Patients, In 2020 Global Pandemic. Biomed J Sci \& Tech Res 28(2)-2020. BJSTR. MS.ID.004618.

Keywords: COVID-19 Convalescent Plasma; Polymerase Chain Reaction Test; SARSCov-2; Convalescent Plasma; Intravenous Immunoglobulins; Passive Immunization

Abbreviations: CCP: COVID-19 Convalescent Plasma; FDA: Food and Drug Administration; CRU: Clinical Research Unit; SARSCo 2: Severe Acute Respiratory Syndrome Coronavirus; MERS: Middle East Respiratory Syndrome

\section{ABSTRACT}

Background and Objective: The Main theme of this Article is to prove the effectiveness and use of Convalescent Plasma therapy in successful prevention and treatment of COVID-19 novel corona Virus critical Patients in 2020 Global Pandemic.

Methods: The Author of this article has chosen random research articles and their published data about successful treatment of COVID-19 patients with Convalescent plasma transfusion. Examples of the 14 different Case reports, Case series and Clinical trials for Convalescent plasma transfusion in china, Taiwan and South Korea proving that CP transfusion helps to improve the health conditions of Patients.

Results: By looking at three tables of 14 Examples of different studies (Case reports, Case series and Clinical trials) in the Methods section the author has given then proof that Convalescent Plasma Treatment work effectively with COVID-19 patients. Measure and statistical Analysis is completed by using SPSS 19 statistic software which shows in bar chart on the 14 studies on COVID-19 patients and percentage of successful or not, the CP Treatment with other western medicines.

Conclusion: To conclude the study, while there is no vaccine currently available for COVID-19 patients the treatment with Convalescent Plasma with other western medicines saves lives of hundreds of thousands of patients in COVID-19 Pandemic. There is need of more advance research and action to find out the Treatment of COVID-19 Pandemic. Global health including public health preventive medicine has failed the world in this current COVID-19 Pandemic when more than Quarter million people died all around the world and approximately 4.2 Million people suffered from this deadly COVID-19 Pandemic.

\section{Introduction}

Use of Convalescent Plasma for COVID-19, two case series were recently compiled in China examining the therapeutic use of CP in patients with COVID-19 [1]. Between the two studies a total of 15 patients were treated all were severely ill before transfusion and were positive for SARS-CoV-2 by PCR. Donor plasma neutralizing antibody titer was tested ( $\geq 1: 40$ in the 5 -patient study; $\geq 1: 640$ in the 10-patient study). All plasma was treated with methylene blue photochemistry and stored at $4^{\circ} \mathrm{C}$ (never frozen). Both studies showed improvement in many respects, including clearance of the virus decreased need for supplemental oxygen and mechanical ventilation, normalization of laboratory values, and improvement of radiologic pulmonary findings. Of note in the 10-patient study recovery was faster in patients receiving $\mathrm{CP}$ before 14 dpoi than in those receiving it later [1]. The global fight against coronavirus disease 2019 (COVID-19) is largely based on strategies to boost immune responses to Severe Acute Respiratory Syndrome Coronavirus 2 (SARS-CoV-2) and prevent its severe course and complications [2].

The human defense may include antibodies which interact with SARS-CoV-2 and neutralize its aggressive actions on multiple organ 
systems. Protective cross-reactivity of antibodies against measles and other known viral infections has been postulated primarily as a result of the initial observations of asymptomatic and mild COVID-19 in children. Uncontrolled case series have demonstrated virus-neutralizing effect of convalescent plasma supporting its efficiency at early stages of contracting SARS-CoV-2. Given the variability of the virus structure, the utility of convalescent plasma is limited to the geographic area of its preparation, and for a short period of time. Intravenous immunoglobulin may also be protective in view of its nonspecific antiviral and immunomodulatory effects. Finally, human monoclonal antibodies may interact with some SARS-CoV-2 proteins inhibiting the virus-receptor interaction and prevent tissue injury [2] (Figure 1).

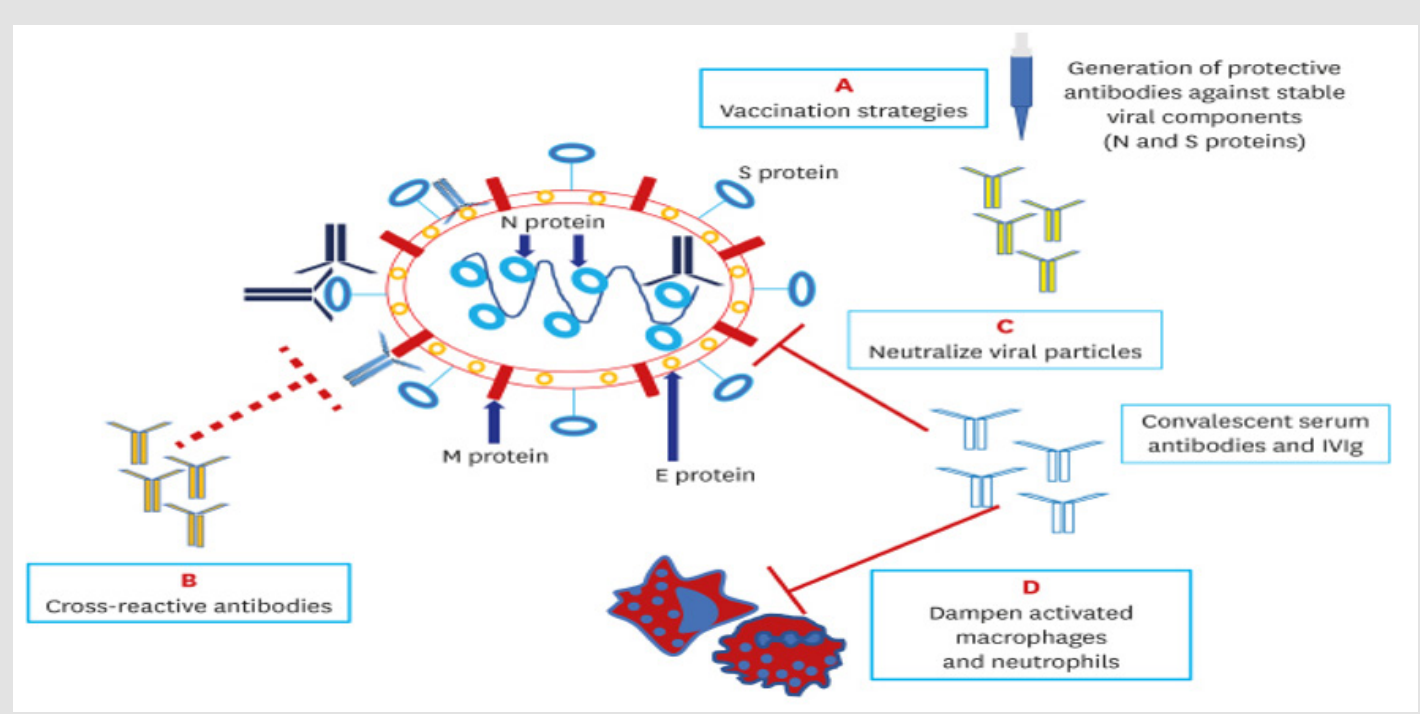

Figure 1.

As transfusion medicine specialists we understood the potential that convalescent plasma could play early in the management of patients with COVID-19 [3]. However, with no guidance from the Food and Drug Administration (FDA) we couldn't begin to establish a program for COVID-19 Convalescent Plasma (CCP). That changed on March 24, 2020, when the FDA issued its first guidance on this topic. The rules were clearly identified subjects with molecularly confirmed COVID-19, and after they have been asymptomatic for 14 days, test them to confirm they were no longer infectious and that they are eligible to donate CCP. With a small hospital-based donor center an academic medical center that had implemented molecular testing for COVID-19 and an established Clinical Research Unit (CRU), we realized we were set to establish and implement a program quickly [3].
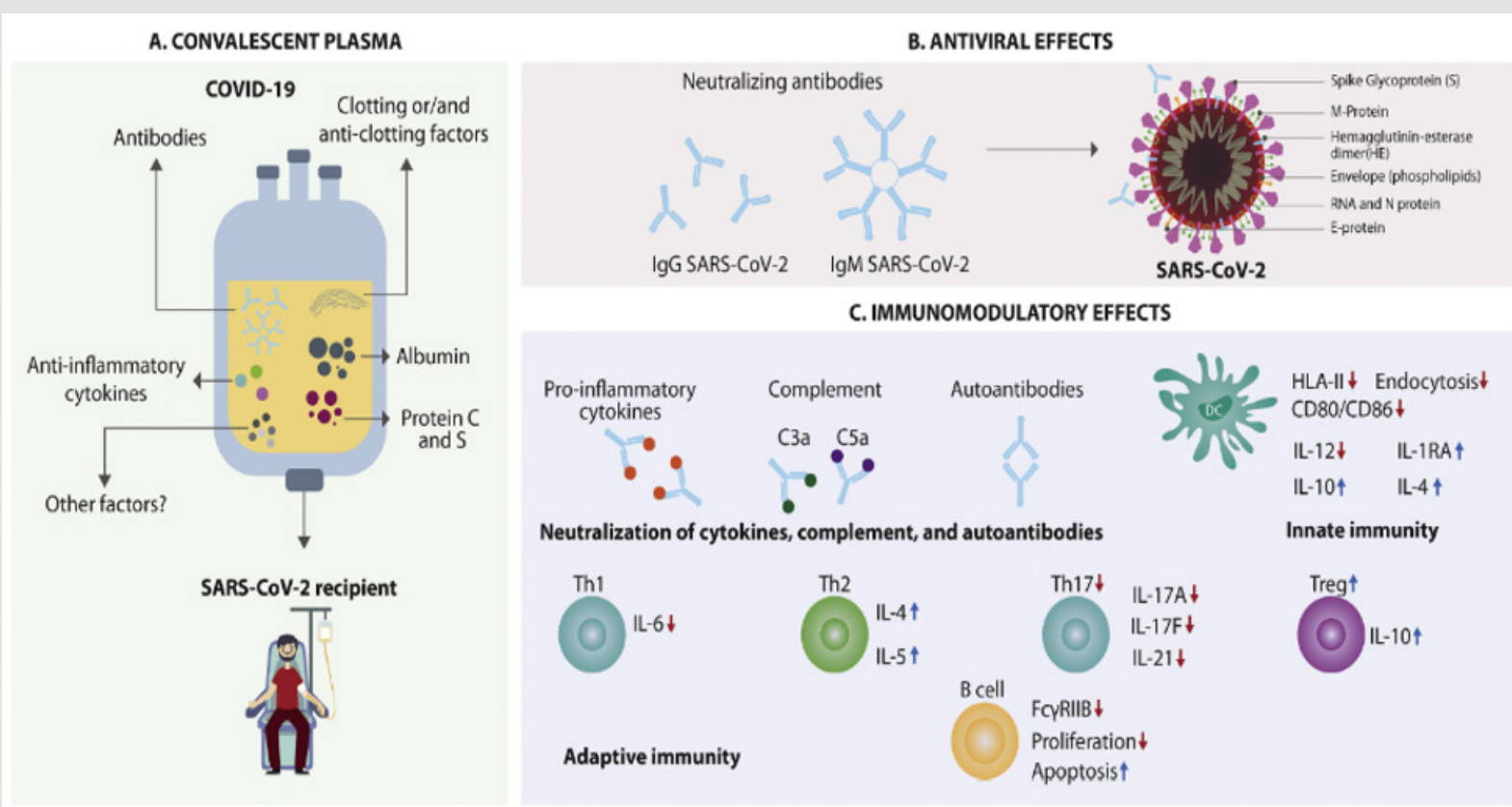

Figure 2. 
Severe Acute Respiratory Syndrome Coronavirus 2 (SARSCoV-2) is responsible of the coronavirus disease 2019 (COVID-19) pandemic [4]. Therapeutic options including antimalarials, antivirals, antibiotics and vaccines are under study. Meanwhile the current pandemic has called attention over old therapeutic tools to treat infectious diseases. Convalescent plasma (CP) constitutes the first option in the current situation, since it has been successfully used in other coronaviruses outbreaks. Herein, we discuss the possible mechanisms of action of $\mathrm{CP}$ and their repercussion in COVID-19 pathogenesis including direct neutralization of the virus, control of an overactive immune system (i.e., cytokine storm, Th1/ Th17 ratio, complement activation) and immunomodulation of a hypercoagulable state [4] (Figure 2).

Previous study reported a higher severe status rate and mortality rate in male patients in China [5]. However, the reason underlying this difference has not been reported. Convalescent plasma containing high level of SARS-CoV-2 IgG antibody has been used in clinical therapy and achieved good effects in China. In this study to compare the differences of SARS-CoV-2 IgG antibody between male and female patients a total number of 331 patients confirmed SARS-CoV-2 infection were enrolled. Serum of these patients were collected during hospitalization and detected for SARS-CoV-2 IgG antibody. Our data showed that the concentration of IgG antibody in mild general and recovering patients showed no difference between male and female patients. In severe status compared with male patients, there were more female patients having a relatively high concentration of serum SARS-CoV-2 IgG antibody. In addition, the generation of IgG antibody in female patients was stronger than male patients in disease early phase. Our study identified a discrepancy in SARS-CoV-2 IgG antibody level in male and female patients which may be a potential cause leading to different outcome of COVID-19 between sex [5].

As more and more patients recover from coronavirus disease 2019 (COVID-19) in the coming weeks convalescent plasma will become increasingly accessible as a treatment option [6]. The first case series describing the use of convalescent plasma to treat critically ill patients with COVID-19 showed clinical improvement and a decline in viral load in all treated patients serving as a proofof-concept for this strategy. However, evidence from animal models of severe acute respiratory syndrome coronavirus (SARS-CoV) suggests that the role of antibodies in the pathogenesis of highlypathogenic coronaviruses is complex. While convalescent plasma has potential to benefit a large number of patients its overall safety and the appropriate timing of administration need further study. In the interest of avoiding harms convalescent plasma should undergo the same rigorous scientific approach as other experimental treatments [6].

\section{Methods}

The Author of this article has chosen random research articles and their published data about successful treatment of COVID-19 patients with Convalescent plasma transfusion. Examples of the 20 different Case reports, case series and clinical trials for Convalescent plasma transfusion in china, Taiwan and South Korea proving that CP transfusion helps to improve the health conditions of Patients (Tables 1 \& 2) and Chart 1.

Table 1: 10 Examples of Different studies Case reports [4], case series and clinical trials for Convalescent plasma transfusion in china, Taiwan and South Korea proving that CP transfusion helps to improve the health conditions of Patients.

\begin{tabular}{|c|c|c|c|c|c|c|c|}
\hline Author & Country & Study Design & Viral etiology & Not CP Treatment & CP Intervention & Outcome & Mortality \\
\hline $\begin{array}{l}\text { 1.Shen et al. } \\
\qquad(2020)\end{array}$ & China & Case series & COVID-19 & $\begin{array}{l}\text { All patients received } \\
\text { antiviral management } \\
\text { during treatment. }\end{array}$ & $\begin{array}{l}\text { CP 200-250 } \\
\text { ml two } \\
\text { consecutive } \\
\text { transfusions } \\
\text { CP } 200 \mathrm{ml} \\
\text { single dose }\end{array}$ & $\begin{array}{l}\text { Improvement } \\
\text { in viral load } \\
\text { and increase } \\
\text { in antibodies }\end{array}$ & $\begin{array}{c}0 \% \\
\text { intervention } \\
\text { group }\end{array}$ \\
\hline $\begin{array}{l}\text { 2.Duan et al. } \\
\qquad(2020)\end{array}$ & China & Clinical trial & COVID-19 & $\begin{array}{c}\text { Ribavirin, } \\
\text { Cefoperazone, } \\
\text { Levoflaxacin, } \\
\text { Methylprednisolone, } \\
\text { Interferon, Peramivir, } \\
\text { Caspofungin. }\end{array}$ & $\begin{array}{l}\text { СР } 200 \mathrm{ml} \\
\text { single dose }\end{array}$ & $\begin{array}{c}\text { Viral load } \\
\text { improvement } \\
\text { and lung } \\
\text { imaging }\end{array}$ & $\begin{array}{c}\text { Reduction of } \\
\text { viral load and } \\
\text { improvement in } \\
\text { lung images }\end{array}$ \\
\hline 3.Ye et al. (2020) & China & Case series & COVID-19 & Not reported & $\begin{array}{l}\text { CP 200-250 } \\
\text { ml two } \\
\text { consecutive } \\
\text { transfusions }\end{array}$ & $\begin{array}{c}\text { Reduction of } \\
\text { viral load and } \\
\text { increase of } \\
\text { SARS-CoV-2 } \\
\text { IgG and IgM } \\
\text { antibodies }\end{array}$ & $\begin{array}{l}0 \% \\
\text { intervention } \\
\text { group }\end{array}$ \\
\hline
\end{tabular}




\begin{tabular}{|c|c|c|c|c|c|c|c|}
\hline $\begin{array}{l}\text { 4.Anh et al. } \\
\text { (2020) }\end{array}$ & South Korea & Case report & COVID-19 & $\begin{array}{l}\text { Lopinavir/Ritonavir, } \\
\text { hydroxychloroquine } \\
\text { and } \\
\text { empirical } \\
\text { antibiotics }\end{array}$ & Not reported & $\begin{array}{c}\text { Reduction of } \\
\text { viral load and } \\
\text { increase of } \\
\text { SARS-CoV-2 } \\
\text { IgG and IgM }\end{array}$ & $\begin{array}{c}0 \% \\
\text { intervention } \\
\text { group }\end{array}$ \\
\hline $\begin{array}{l}\text { 5.Soo et al } \\
(2004)\end{array}$ & China & $\begin{array}{l}\text { Retrospective } \\
\text { comparison } \\
\text { of cases }\end{array}$ & SARS-CoV & $\begin{array}{c}\text { Intervention Group: } \\
\text { Ribavirin, } 3 \text { doses } \\
\text { Methylprednisolone } \\
(1 \cdot \\
5 \mathrm{~g}) . \\
\text { Control group: } \\
\text { Ribavirin, } 4 \text { or more } \\
\text { doses of } \\
\text { Methylprednisolone } \\
(1.5 \mathrm{~g}) .\end{array}$ & $\begin{array}{l}\text { CP 200-400 } \\
\text { ml days } 11 \\
\text { and } 42 \text { after } \\
\text { the onset of } \\
\text { symptoms }\end{array}$ & $\begin{array}{c}\text { length of } \\
\text { hospital stay, } \\
\text { adverse } \\
\text { events }\end{array}$ & $\begin{array}{c}23 \% \text { reduction } \\
\qquad(p=0.03)\end{array}$ \\
\hline $\begin{array}{l}\text { 6.Cheng et al } \\
\text { (2005) }\end{array}$ & China & Case series & SARS-CoV & Not reported & $\begin{array}{l}\text { СР } 279 \mathrm{ml} \text { per } \\
\text { day } 14\end{array}$ & $\begin{array}{c}\text { Mortality, } \\
\text { length of } \\
\text { hospital stay, }\end{array}$ & $\begin{array}{l}12.50 \% \\
\text { intervention } \\
\text { group. }\end{array}$ \\
\hline $\begin{array}{l}\text { 7.Nie et al. } \\
\text { (2003) }\end{array}$ & China & Case series & SARS-CoV & Not reported & $\begin{array}{l}\text { CP unknown } \\
\text { dose }\end{array}$ & Mortality & $\begin{array}{c}0 \% \\
\text { intervention } \\
\text { group } \\
\end{array}$ \\
\hline $\begin{array}{c}\text { 8.Yeh et al } \\
\text { (2005) }\end{array}$ & Taiwan & Case series & SARS-CoV & $\begin{array}{l}\text { Ribavirin, Moxifloxacin, } \\
\text { Methylprednisolone }\end{array}$ & $\begin{array}{l}\text { CP unknown } \\
\text { dose on day } \\
11 \text { of symptom } \\
\text { onset }\end{array}$ & $\begin{array}{l}\text { Mortality, } \\
\text { antibodies, } \\
\text { viral load, } \\
\text { adverse } \\
\text { events }\end{array}$ & $\begin{array}{c}0 \% \\
\text { intervention } \\
\text { group }\end{array}$ \\
\hline $\begin{array}{l}\text { 9.Zhou et al. } \\
\text { (2003) }\end{array}$ & China & Case series & SARS-CoV & $\begin{array}{l}\text { All patient received } \\
\text { Levofloxacin, Steroids, } \\
\text { Mechanical ventilation. }\end{array}$ & $\begin{array}{c}\text { CP } 50 \mathrm{ml} \\
\text { single dose on } \\
\text { symptom onset }\end{array}$ & Mortality, & $7 \%$ reduction \\
\hline $\begin{array}{c}\text { 10.Ko et al. } \\
\text { (2018) }\end{array}$ & South Korea & Case series & SARS-CoV & Steroids & $\begin{array}{c}\text { CP } \\
\text { Unspecified } \\
\text { dose } \\
\end{array}$ & Antibody titers & $\begin{array}{c}0 \% \\
\text { intervention } \\
\text { group } \\
\end{array}$ \\
\hline
\end{tabular}

Table 2: Summary of 19 Patients (Examples11 -13) 3 Cases Series (19 Patients) examining the use of convalescent plasma in the setting of SARS-CoV-2 [7].

\begin{tabular}{|c|c|c|c|c|c|}
\hline Study(year) & $\begin{array}{l}\text { Number of } \\
\text { patients (age } \\
\text { range in years) }\end{array}$ & $\begin{array}{c}\text { Patient } \\
\text { characteristics }\end{array}$ & $\begin{array}{c}\text { Volume of CP } \\
\text { transfused(average } \\
\text { day from admission) }\end{array}$ & CP antibody profile & $\begin{array}{c}\text { Summary of outcomes observed } \\
\text { post-transfusion (ratio of } \\
\text { patients demonstrating } \\
\text { outcome) }\end{array}$ \\
\hline $\begin{array}{l}\text { 11. Shen et al. } \\
\text { (2020) }\end{array}$ & $\begin{array}{c}5 \text { Patients (Age } \\
\text { 36-73) }\end{array}$ & $\begin{array}{c}\text {-qRT- PCR confirmed } \\
\text { COVID-19infection } \\
\text { - severe PNA } \\
\text { - Pao2/Fio2 b300 } \\
\text { mmHG } \\
\text {-mechanically } \\
\text { ventilated }\end{array}$ & $400 \mathrm{~mL}(18.2)$ & $\begin{array}{l}\text { SARS-CoV-2-specifi- } \\
\text { cantibodytiter-1:1000 } \\
\text { neutralizingantibodyti- } \\
\text { ter-1: } 40\end{array}$ & $\begin{array}{c}\text {-Increase in Pao2/Fio2 within } 12 \\
\text { days } \\
\text {-Decrease in viral loads within } 12 \\
\text { days } \\
\text {-Increase in SARS-CoV-2-specific } \\
\text { and neutralizing antibody titers } \\
\text {-Resolution of ARDS within } 12 \\
\text { days(4/5) } \\
\text { - Mechanical ventilation weaned } \\
\text { within14 days (3/5) } \\
\text {-Discharged between days 51-55 } \\
(3 / 5)\end{array}$ \\
\hline
\end{tabular}




\begin{tabular}{|c|c|c|c|c|c|}
\hline $\begin{array}{l}\text { 12. Duan et al. } \\
-2020\end{array}$ & $\begin{array}{c}\text { 10Patients (Age } \\
34-78)\end{array}$ & $\begin{array}{l}\text { - qRT-PCR confirmed } \\
\text { COVID-19infection } \\
\text { - 2/4 of the following: } \\
\text { 1) } \geq 18 \text { years } \\
\text { 2) respiratory distress } \\
\text { 3) } \mathrm{O}_{2} \text { saturation b93\% } \\
\text { at rest } \\
\text { 4)Pao } 2 / \text { Fio } 2 \mathrm{~b} 300 \\
\text { mmHg }\end{array}$ & $200 \mathrm{~mL}(16.5)$ & $\begin{array}{c}\text { Neutralization } \\
\text { antibody titer } \\
\text { N1:640 }\end{array}$ & $\begin{array}{c}\text {-Clinical symptoms were } \\
\text { significantly within } 3 \text { days } \\
\text {-Increase in } \mathrm{O}_{2} \text { saturation within } \\
3 \text { days } \\
\text {-Trend in increased lymphocyte } \\
\text { counts } \\
\text {-Trend in decreased C-reactive } \\
\text { protein } \\
\text {-Imaging showed varying degrees } \\
\text { of absorption of lung lesions } \\
\text { within 7days } \\
\text {-Undetectable viral load }(7 / 10)\end{array}$ \\
\hline $\begin{array}{l}\text { 13. Zhang } \\
\text { et al. } \\
-2020\end{array}$ & $\begin{array}{c}4 \text { Patients (Age } \\
31-73 \text { ) }\end{array}$ & $\begin{array}{l}\text { - Confirmed COVID-19 } \\
\text { infection(3/4 RT-PCR } \\
\text { positive) } \\
\text { - Respiratory failure } \\
\text { requiring mechanical } \\
\text { ventilation (2required } \\
\text { ECMO) }\end{array}$ & 200-2400mL (15.25) & Not measured & $\begin{array}{c}\text {-Negative qRT-PCR } \\
\text {-Imaging showed absorption, or } \\
\text { partial absorption, of lung lesions } \\
\text {-Discharged between days } 18 \text { - } \\
43(3 / 4) \\
\text {-Remained hospitalized with multi } \\
\text { organ failure }(1 / 4)\end{array}$ \\
\hline
\end{tabular}

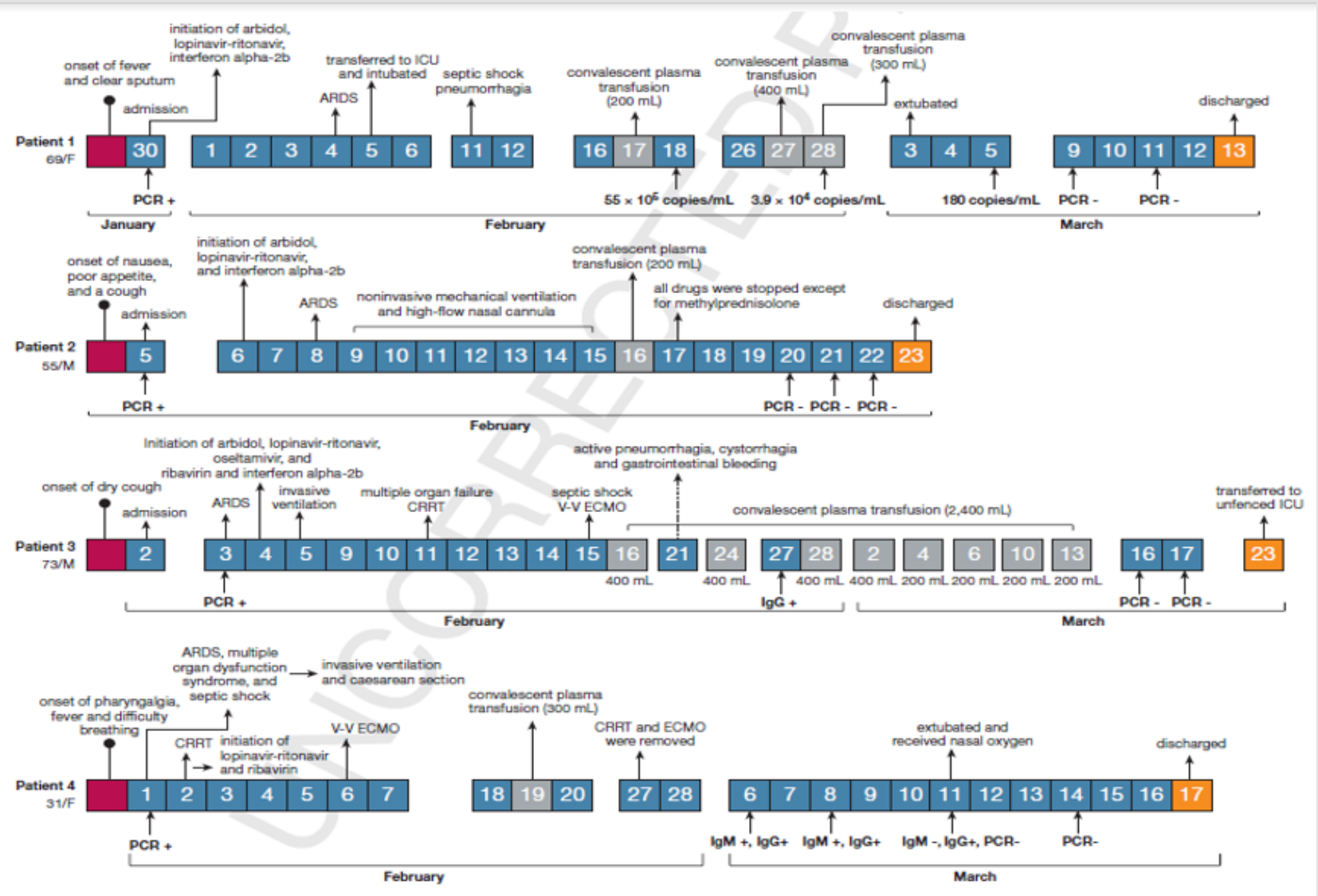

$\square$ Quarantined $\square$ Hospitalized $\square$ Transfused with convalescent plasma $\square$ Discharged

\section{Chart 1.}


Measure and statistical Analysis:(IBM) [7]:

1. (Rojas M, Rodriguez Y, Monsalve DM et al, 2020) Examples of 10 studies case series and clinical trials for Convalescent plasma transfusion in china, Taiwan and South Korea (Example Figure 1).

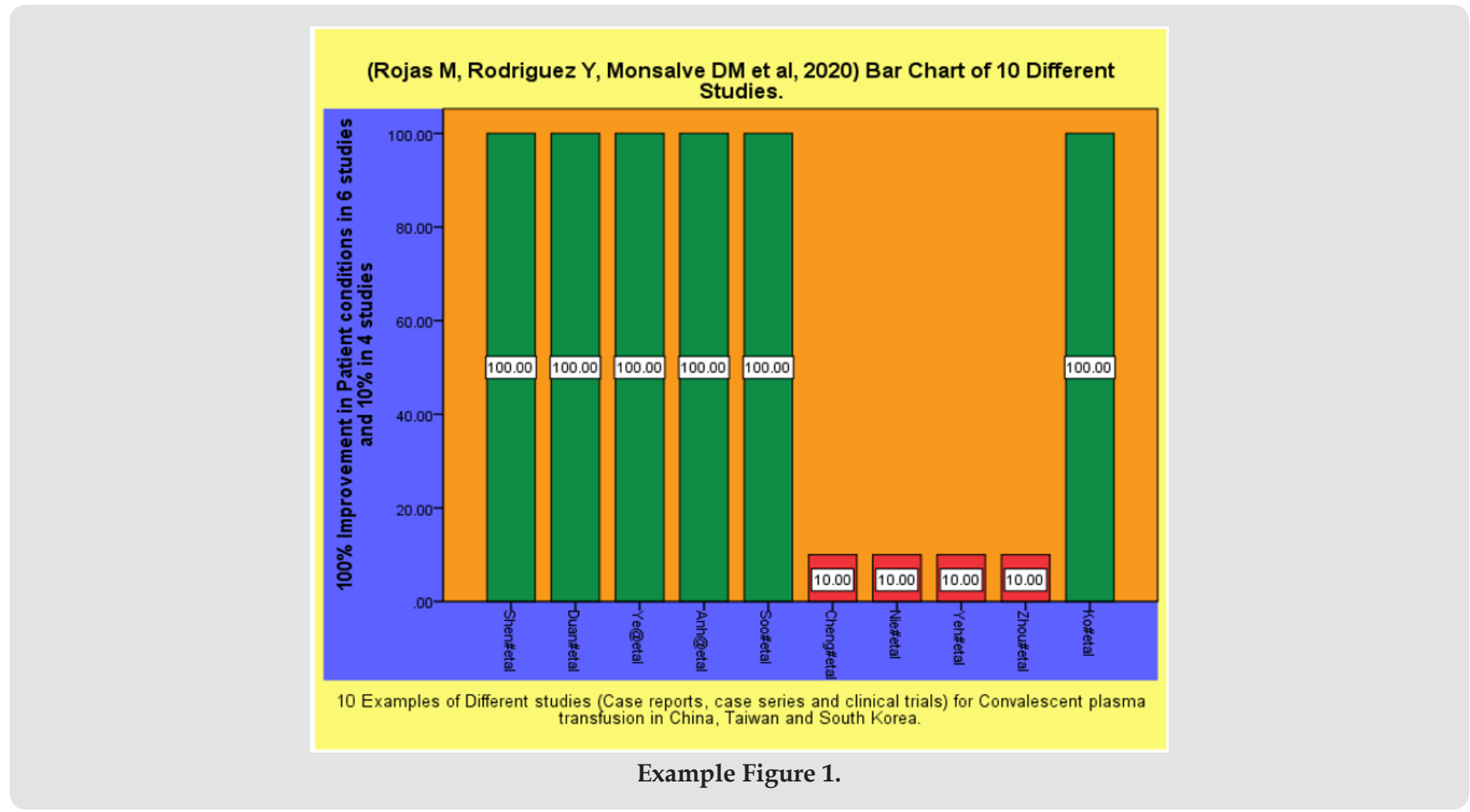

2. (Sullivan HC, Roback JD, 2020) Summary of 19 Patients (Examples 11 -13) 3 Cases Series examining the use of convalescent plasma in the setting of SARS-CoV-2 (Example Figure 2).

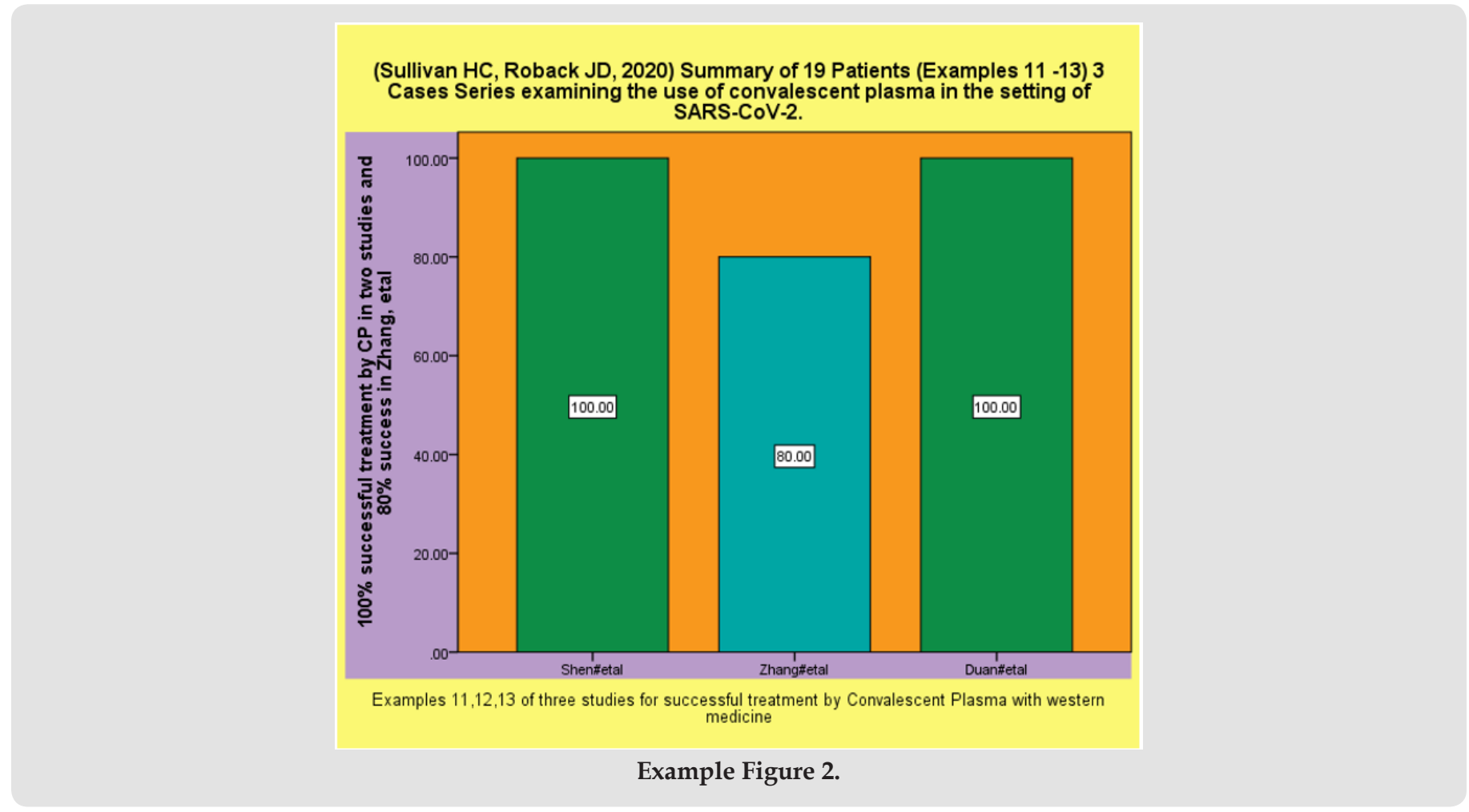

3. (14 $4^{\text {th }}$ Example) of 4 Patients (Bin Zhang, Shuyi Liu, Tan Tan, Wenhui Huang et al. 2020) (Example Figure 3). 


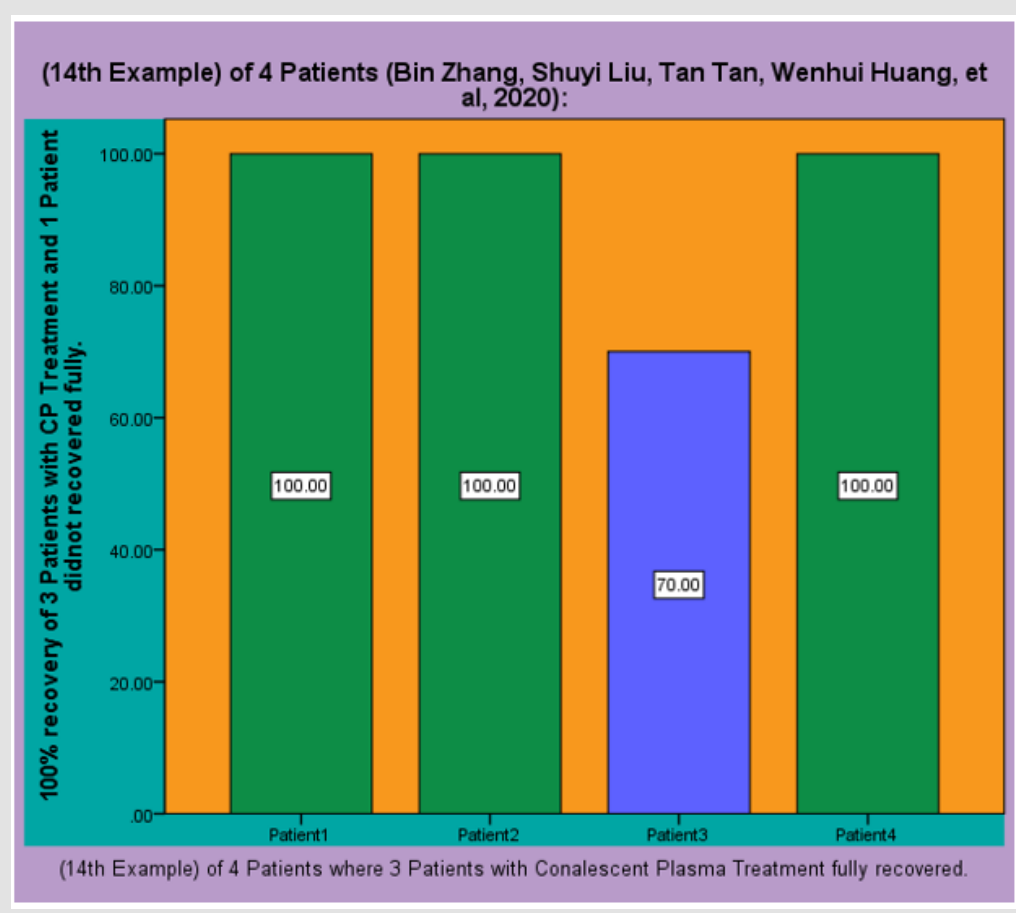

Example Figure 3.

\section{Results}

By looking at three tables of 14 Examples of different studies (Case reports, Case series and Clinical trials) in the Methods section the author has given then proof that Convalescent Plasma Treatment work effectively with COVID-19 patients. Measure and statistical Analysis is completed by using SPSS 19 statistic software which shows in bar chart on the 14 studies on COVID-19 patients and percentage of successful or not, the CP Treatment with other western medicines. One of the hopeful treatments that has emerged is convalescent plasma (CP) or immune plasma [10]. $\mathrm{CP}$ which is plasma that is collected from an infected individual such as by COVID-19 (i.e. human anti-SARS-CoV-2 plasma) is then transfused into infected patients as a postexposure prophylaxis. Unlike immunoglobulin (IgG)derived antibodies such as plasmaderived monoclonal antibodies CP is a passive antibody therapy that showed some success as a neutralizing antibody against other coronavirus epidemics SARS-1 and Middle East Respiratory Syndrome (MERS) in the first two decades of the 2000s. CP derived antibodies can neutralize a virus by preventing replication (e.g. by complement activation or phagocytosis) or by binding without interfering with replication.

In China five critically ill patients infected with COVID-19 (also with acute respiratory distress syndrome) received a transfusion of SARS-CoV-2-specific IgG (binding titer > 1:1000; neutralization titer $>40$ ) 10-22 days after admission. Their clinical status improved with three having been discharged after 51-55 days of hospitalization. It should be noted that these patients were also supported by a mechanical ventilator and had also received antiviral agents (combinations of lopinavir, ritonavir, interferon $\alpha-1 b$, favipiravir, arbidol, and/or darunavir) and methylprednisolone a steroid [10]. Use of convalescent plasma transfusions could be of great value in the current pandemic of coronavirus disease (COVID-19) given the lack of specific preventative and therapeutic options [11]. This convalescent plasma therapy is of particular interest when a vaccine or specific therapy is not yet available for emerging viruses such as severe acute respiratory syndrome coronavirus 2 (SARS-CoV-2) which causes COVID-19. This report summarizes existing literature around convalescent plasma as a therapeutic option for COVID-19. It also includes recommendations for establishing a convalescent plasma program enhancement consideration for convalescent plasma and considerations around pathogen reduction treatment of convalescent plasma. Time is of the essence to set up protocols for collection, preparation, and administration of apheresis collected convalescent plasma in response to the current pandemic. The immediate use of convalescent plasma provides prompt availability of a promising treatment while specific vaccines and treatments are evaluated and brought to scale. Further development of improved convalescent plasma, vaccines and other therapeutics depends on quick generation of additional data on pathogenesis and immune response [11].

The recent emergence of COVID-19 pandemic has reassessed the usefulness of historic convalescent plasma transfusion (CPT) [12]. This review was conducted to evaluate the effectiveness of CPT therapy in COVID-19 patients based on the publications reported till date. We included 5 studies reporting CPT to COVID-19 patients. The main findings from available data are as follows:

a) Convalescent plasma may reduce mortality in critically ill patients 
b) Increase in neutralizing antibody titers and disappearance of SARS-CoV-2 RNA was observed in almost all the patients after CPT therapy

c) Beneficial effect on clinical symptoms after administration of convalescent plasma. Based on the limited scientific data CPT therapy in COVID-19 patient appears safe clinically effective and reduces mortality.

Well-designed large multicenter clinical trial studies should be conducted urgently to establish the efficacy of CPT to COVID-19 patients [12]. As deaths from coronavirus disease 2019 (COVID-19) continue to mount desperation has driven physicians to try therapies backed by little or no evidence [13]. Taken from healthy people or in the earliest reported cases animals who have recovered from the infectious disease of interest, antibody-rich convalescent plasma is thought to give recipients immune systems a running start.

To explain how desperate the need is we probably have at least 300 COVID-19patients in the hospital today over a third of them intubated anesthesiologist Elliott Bennett-Guerrero MD, said in mid-April. He's the principal investigator of a just launched convalescent plasma trial at Stony Brook Hospital in New York with a planned enrollment of up to 500 hospitalized patients with COVID-19 a third of whom probably will be intubated. We are at lightning speed ramping up production and processes for collecting convalescent plasma Bennett-Guerrero explained. We do not know if this is safe and effective Bennett Guerrero acknowledged in an interview. We hope it is because we desperately want to help our patients [13].

Figure 3 Convalescent Plasma: [14].

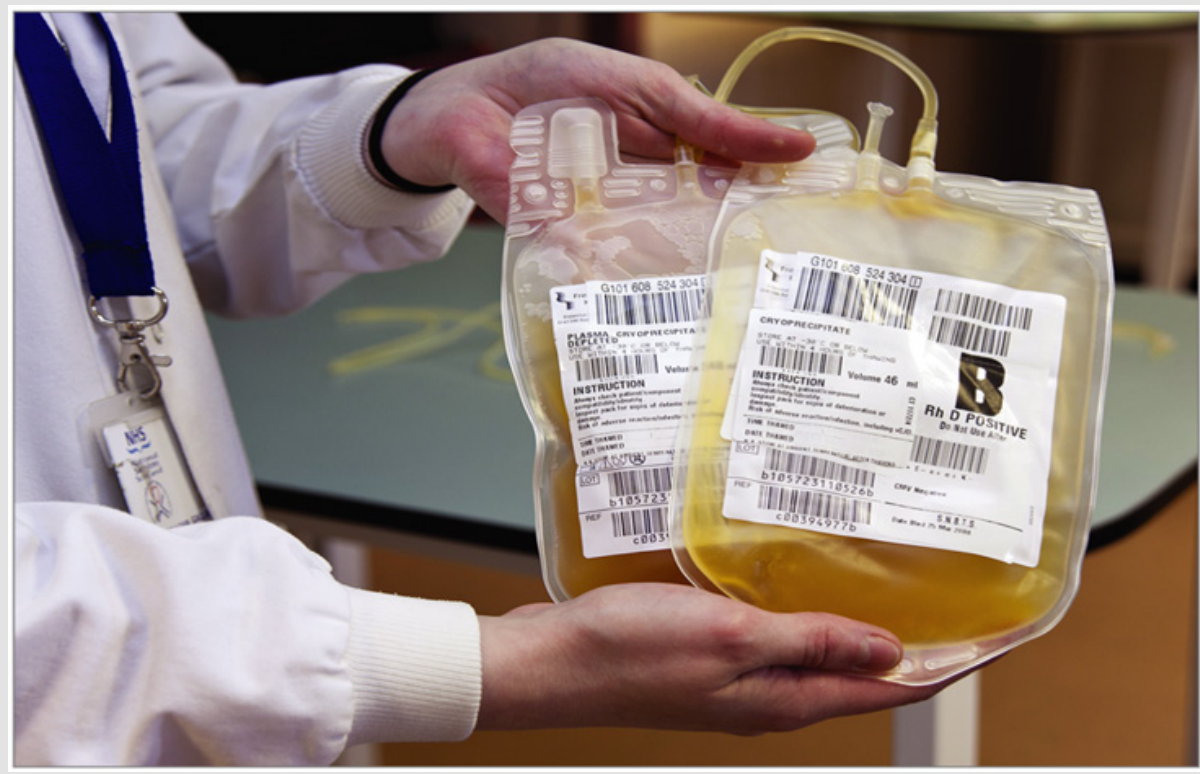

Figure 3: Convalescent Plasma [10].

\section{Discussion}

Currently the severe acute respiratory syndrome coronavirus 2 (SARS-CoV-2) disease 2019 (COVID-19) has been reported in almost all countries globally and no effective therapy has been documented for COVID-19 and the role of convalescent plasma therapy is unknown. In current study 6 COVID-19 subjects with respiratory failure received convalescent plasma at a median of 21.5 days after first detection of viral shedding all tested negative for SARS-CoV-2 RNA by 3 days after infusion and 5 died eventually. In conclusion convalescent plasma treatment can discontinue SARSCoV-2 shedding but cannot reduce mortality in critically end-stage COVID-19 patients and treatment should be initiated earlier [15].

First of all, there is quite a hurdle in the form of convalescent plasma collection production and use [16]. Several logistic difficulties have to be overcome as outlined by Roback and Guarner. Protection of donor's welfare blood safety and quality are important and must not be compromised. Secondly treatment with human immunoglobulin during the SARS-CoV-2 pandemic has been associated with a significantly increased risk of same-day thrombotic events (from 0.04 to $14.9 \%$ ). Thirdly, due to the lack of full knowledge of the biology of SARS-CoV-2, including virus variability and mutations plasma collected locally may better reflect the circulating virus in the population. As of 28 April 2020, there have not been any published conclusive results for a specific effective agent. Before a vaccine becomes available observational studies pre-clinical and clinical research are warranted to shed some light on COVID-19 characteristics and possible therapies. Plasma and H-IVIG of recovered patients are a tried and tested approach that could prove helpful in the short term [16].

The pandemic spread of a novel coronavirus SARS coronavirus- 2 (SARS-CoV-2) as a cause of acute respiratory illness named Covid-19, is placing the healthcare systems of many countries under unprecedented stress [17]. Global economies are also spiraling 
towards a recession in fear of this new life-threatening disease. Vaccines that prevent SARS-CoV-2 infection and therapeutics that reduces the risk of severe Covid-19 are thus urgently needed. A rapid method to derive antiviral treatment for Covid-19 is the use of convalescent plasma derived hyperimmune globulin. However, both hyperimmune globulin and vaccine development face a common hurdle the risk of antibody mediated disease enhancement. The goal of this review is to examine the body of evidence supporting the hypothesis of immune enhancement that could be pertinent to Covid-19. We also discuss how this risk could be mitigated so that both hyperimmune globulin and vaccines could be rapidly translated to overcome the current global health crisis [17].

Coronavirus Disease 19 (COVID-19) represents a public health threat worldwide and Italy at the present time is considered the epicenter of this severe infection in the western world. Unfortunately, no standardized therapy does exist for COVID-19 and a number

Table 3: Antibody levels of six donors recovered from COVID- 19.

\begin{tabular}{|c|c|c|c|c|c|}
\hline Donor No. & Blood group & $\begin{array}{c}\text { Days from symptoms onset } \\
\text { to plasma collecting }\end{array}$ & $\begin{array}{l}\text { Days from discharge } \\
\text { to plasma collecting }\end{array}$ & $\begin{array}{l}\text { Anti-SARS-CoV-2 IgM } \\
\text { levels (OD ratio) }^{\mathrm{a}}\end{array}$ & $\begin{array}{l}\text { Anti-SARS-CoV-2 IgG } \\
\text { levels (OD ratio) }{ }^{\mathrm{a}, \mathrm{b}}\end{array}$ \\
\hline A & A & 29 & 13 & 1.47 & 7.58 \\
\hline $\mathrm{B}$ & 0 & 36 & 17 & 1.22 & 6.59 \\
\hline $\mathrm{C}$ & B & 37 & 23 & 1.55 & 7.84 \\
\hline $\mathrm{D}$ & $A$ & 46 & 27 & 2.01 & 3.92 \\
\hline $\mathrm{E}$ & 0 & 40 & 22 & 1.95 & 7.52 \\
\hline $\mathrm{F}$ & $\mathrm{A}$ & 39 & 27 & 5.63 & 8.36 \\
\hline
\end{tabular}

Recently [20] the US Food and Drug Administration in United States has approved the use of plasma from recovered patients to treat seriously ill COVID-19-infected individuals. The transfused plasma must be obtained from donors tested negative for COVID-19 when plasma collection is performed before day 28 of clinical recovery and must be collected from recovered patients without symptoms for at least 14 days. Cheng et al. investigated 1775 SARS patients and found that 80 patients transfused with SARS convalescent plasma had a lower mortality rate, compared to non-transfused patients ( $12.5 \%$ vs. $17 \%)$.Hung and colleagues conducted a prospective cohort study offering treatment with $\mathrm{H} 1 \mathrm{~N} 1$ convalescent plasma (antibody titer $>1: 160$ ) to infected patients in intensive care. They found that the relative risk of mortality by an H1N1 infection was significantly reduced in patients transfused with convalescent plasma compared to a control group of patients who declined the plasma treatment $(20.0 \%$ vs. $54.8 \%$; $p=0.01)$ [20].

Human-to-human transmission [21] of SARS-CoV-2 act through respiratory droplets and direct contact though fecal-oral transmission might be possible. The incubation period can range between 0 up to 24 days with an average of 3 days. Common early symptoms include fever, dry cough, and malaise. Later on, symptoms such as dyspnea, vomiting, and diarrhea tend to appear. Moreover, the virus was characterized by rapidly progressive pneumonia a of investigational drugs for use in patients with life-threatening COVID-19 infections have been tried. One investigational treatment being explored for COVID-19 involves the use of convalescent plasma collected from recovered COVID-19 patients [18]. AntiSARS-CoV-2 virus antibody levels in convalescent plasma (CP) which may be useful in severe Anti-SARS-CoV-2 virus infections have been rarely reported [19]. A total of eight donors were considered for enrollment two of them were excluded because of ineligible routine check. Of the six remaining participants five samples were tested weakly positive by the IgM ELISA. Meanwhile, high titers of IgG were observed in five samples. The patient treated with CP did not require mechanical ventilation 11 days after plasma transfusion and was then transferred to a general ward. Our serological findings in convalescent plasma from recovered patients may help facilitate understanding of the SARS-CoV-2 infection and establish CP donor screening protocol in COVID-19 outbreak [19]. Table 2 shows Antibody levels of six Donors recovered from COVID-19 (Table 3).

range between 2 to 7 days after early symptoms appear particularly at the elder and pre-conditioned patients. A recent study suggests that SARS-CoV-2 (similar to SARS-CoV) primarily infects ciliated bronchial epithelial cells and type II pneumocytes where it binds to the surface receptor Angiotensin-Converting Enzyme 2 (ACE2) and initiates fusion with the host cells. Passive immunization PI through broadly neutralizing antibodies that bind to the specific antigens of SARS-CoV 2 might be a potential solution to address the immediate health threat of COVID-19 pandemic while vaccines are being developed. The PI approach in treating COVID-19 is discussed herein including a summary of its historical applications to confront epidemics [17]. There are only a few available antiviral treatments which have limited efficacy on COVID-19 at present [21].

The latest Chinese guideline emphasized that Convalescent Plasma (CP) therapy was an emergent treatment for serious COVID-19 cases. Generally, CP has been applied to improve the survival rate of patients with a variety of viral epidemics, including SARS, MERS, influenza, Ebola virus disease, etc. More recently COVID-19 cases have also shown improvement to a certain degree after CP therapy in China. Meanwhile the risk of transfusiontransmitted infections, such as human immunodeficiency virus, hepatitis B virus, hepatitis C virus and syphilis should not be neglected. In conclusion CP therapy as a potential treatment for COVID-19 there are still some challenges to be dealt with. But 
considering the absence of specific treatment we recommend that $\mathrm{CP}$ therapy could be an alternative option in emergent situation of COVID-19 [21].

\section{Conclusion}

To conclude the study, while there is no vaccine currently available for COVID-19 patients the treatment with Convalescent Plasma with other western medicines saves lives of hundreds of thousands of patients in COVID-19 Pandemic. There is need of more advance research and action to find out the Treatment of COVID-19 Pandemic. Global health including public health preventive medicine has failed the world in this current COVID-19 Pandemic when more than Quarter million people died all around the world and approximately 4.2 Million people suffered from this deadly COVID-19 Pandemic.

\section{References}

1. Paul Barone, Robert A DeSimone (2020) Convalescent Plasma to Treat Coronavirus Disease 2019 (Covid-19): Considerations for Clinical Trial Design. Transfusion.

2. Gasparyan AY, Misra DP, Yessirkepov M, Olena Zimba (2020) Perspectives of Immune Therapy in Coronavirus Disease 2019. JKMS Journal of Korean Medical Science 35(18): e176.

3. C Michael Knudson, J Brooks Jackson (2020) COVID-19 Convalescent Plasma: Phase 2. Transfusion.

4. Rojas M, Rodriguez Y, Monsalve DM, Yeny Acosta Ampudia, Bernardo Camacho, et al. (2020) Convalescent plasma in Covid-19: Possible mechanisms of action. Elsevier Autoimmunity reviews 19(7).

5. Fanfan Zeng, Chan Dai, Pengcheng Cai, Jinbiao Wang, Lei Xu, et al. (2020) A comparison study of SARS-CoV-2 IgG antibody between male and female COVID-19 patients: a possible reason underlying different outcome between sex. Journal of Medical Virology.

6. Fleming AB, Raabe V (2020) Current studies of convalescent plasma therapy for COVID-19 may underestimate risk of antibody-dependent enhancement. Elsevier Journal of clinical virology.

7. IBM (2006) IBM SPSS Software.

8. Sullivan HC, Roback JD (2020) Convalescent Plasma: Therapeutic Hope or Hopeless Strategy in the SARS-CoV-2 Pandemic. Elsevier Transfusion Medicine reviews.

ISSN: 2574-1241

DOI: 10.26717/BJSTR.2020.28.004618

Ahsan Ali Siddiqui. Biomed J Sci \& Tech Res

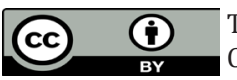

This work is licensed under Creative Commons Attribution 4.0 License

Submission Link: https://biomedres.us/submit-manuscript.php
9. Bin Zhang, Shuyi Liu, Tan Tan, Wenhui Huang, Yuhao Dong, et al. (2020) Treatment with Convalescent Plasma for Critically Ill Patients With SARS-CoV-2Infection. CHEST Journal.

10. Jaime A, Teixeira da Silva (2020) Convalescent plasma: A possible treatment of COVID-19 in India. Elsevier Medical Journal Armed Forces India 76(2): 236-237.

11. Brown BL, McCullough J (2020) Treatment for emerging viruses: Convalescent plasma and COVID-19. Elsevier Transfusion and Apheresis Science 59(3).

12. Rajendran K, Narayanasamy K, Rangarajan J, Rathinam J, Murugan N, et al. (2020) Convalescent plasma transfusion for the treatment of COVID-19: Systematic review. Journal of Medical Virology.

13. Rubin R (2020) Testing an Old Therapy Against a New Disease: Convalescent Plasma for COVID-19. JAMA Network.

14. Qing Lei Zeng, Zu Jiang Yu, Jian Jun Gou, Guang Ming Li, Shu-Huan Ma, et al. (2020) Effect of Convalescent Plasma Therapy on Viral Shedding and Survival in COVID-19 Patients. The Journal of Infectious Diseases.

15. Tamburello A, Marando M (2020) Immunoglobulins or convalescent plasma to tackle COVID-19: buying time to save lives - current situation and perspectives. Swiss Medical Weekly 150.

16. De Alwis R, Chen S, Gan ES, Eng Eong Ooi, et al. (2020) Impact of immune enhancement on Covid-19 polyclonal hyperimmune globulin therapy and vaccine development. Elsevier E Biomedicine 55.

17. Massimo Franchini, Giuseppe Marano, Claudio Velati, Ilaria Pati, Simonetta Pupella, et al. (2020) Operational protocol for donation of anti-COVID-19 convalescent plasma in Italy. Voxsanguinis Journal.

18. Zhang L, Pang R, Xue X, Jingjing Bao, Sheng Ye, et al. (2020) Anti-SARSCoV-2 virus antibody levels in convalescent plasma of six donors who have recovered from COVID-19. Aging COVID-19 12(8): 6536-6542.

19. Langhi DM, Santis GC, Bordin JO (2020) COVID-19 convalescent plasma transfusion. Elsevier Hematology, Transfusion and Cell Therapy. 42(2): 113-115.

20. Alzoughool F, Alanagreh L (2020) Coronavirus drugs: Using plasma from recovered patients as a treatment for COVID-19. International Journal of Risk \& Safety in Medicine 31(2): 47-51.

21. Zhao Q, He Y (2020) Challenges of Convalescent Plasma Therapy on COVID-19. Elsevier Journal of Clinical Virology 127.

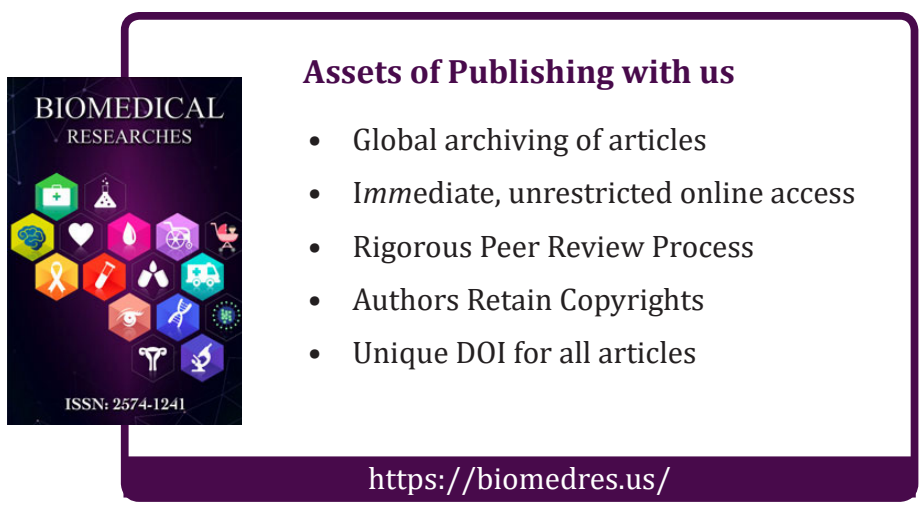

